\title{
The role of corporate image and extension similarity in service brand extensions
}

Citation for published version (APA):

de Ruyter, J. C., \& Wetzels, M. G. M. (2000). The role of corporate image and extension similarity in service brand extensions. METEOR, Maastricht University School of Business and Economics. METEOR Research Memorandum No. 035 https://doi.org/10.26481/umamet.2000035

Document status and date:

Published: 01/01/2000

DOI:

10.26481/umamet.2000035

Document Version:

Publisher's PDF, also known as Version of record

\section{Please check the document version of this publication:}

- A submitted manuscript is the version of the article upon submission and before peer-review. There can be important differences between the submitted version and the official published version of record.

People interested in the research are advised to contact the author for the final version of the publication, or visit the DOI to the publisher's website.

- The final author version and the galley proof are versions of the publication after peer review.

- The final published version features the final layout of the paper including the volume, issue and page numbers.

Link to publication

\footnotetext{
General rights rights.

- You may freely distribute the URL identifying the publication in the public portal. please follow below link for the End User Agreement:

www.umlib.nl/taverne-license

Take down policy

If you believe that this document breaches copyright please contact us at:

repository@maastrichtuniversity.nl

providing details and we will investigate your claim.
}

Copyright and moral rights for the publications made accessible in the public portal are retained by the authors and/or other copyright owners and it is a condition of accessing publications that users recognise and abide by the legal requirements associated with these

- Users may download and print one copy of any publication from the public portal for the purpose of private study or research.

- You may not further distribute the material or use it for any profit-making activity or commercial gain

If the publication is distributed under the terms of Article $25 \mathrm{fa}$ of the Dutch Copyright Act, indicated by the "Taverne" license above, 


\section{The Role of Corporate Image and Extension Similarity in Service Brand Extensions}

Ko de Ruyter

Martin Wetzels

MAXX WORKING PAPER SERIES

Maastricht Academic Center
for research in Services

MAXX Working Paper 2000-01, January $12^{\text {th }}, 2000$ 


\section{The Role of Corporate Image and Extension Similarity in Service Brand}

\section{Extensions}

\section{Introduction}

For many companies the (financial) risks of entering new markets or launching new products or services are quite substantial (Boush and Loken 1991; John and Loken 1992). One way of dealing with these risks is to use the familiarity and prestige, or rather, the image of brands as a leverage for enhancing credibility and unobservable quality (Rao et al. 1997). Moreover, a strong corporate brand image can be used to increase communication efficiency, particularly if the new market is clearly beyond the current market scope of the firm (Keller and Aaker 1997). Therefore, brand extensions are increasingly recognized as a strategic asset by many companies (Hart and Murphy 1998). The prioritization of brand extensions in the business community has been paralleled by a strong recent interest in aspects of branding in the academic marketing literature. Researchers have examined the measurement of brand equity (Keller and Aaker 1997), brand alliances as quality cues (Rao et al. 1997), product ownership effects in consumer response to brand line stretches (Kirmani et al. 1997) and flagship product dilution (Roedder John et al. 1998). However, an analysis of this rapidly accumulating body of knowledge reveals several conceptual and empirical lacunas. To begin with, the focus has been virtually exclusively on brand extensions of tangible goods. Also, much of the research on brand extensions has been conducted within the context of the same or related markets. Not much is known about the brand transfer to other markets. Furthermore, the emphasis has been on individual product category rather than corporate brand extensions (see Keller and Aaker (1997) for a recent exception).

Therefore, a research issue that has remained underexposed concerns the extension of services to unrelated markets by making use of the corporate brand. Yet, this type of service extension is becoming a prevalent phenomenon. For instance, recent deregulation and privatization of key European service markets, such as telecommunications, postal services and public transport, have spurred a number of 
corporate service brand extensions, frequently by service providers active in a myriad of other (international) markets. In the process, these service providers attempt to acquire customer trust on the basis of solidity of their reputation in the market in which they have traditionally been active.

As services consist primarily of intangible properties, corporate service brands may be used to reduce perceived risk and to influence frequently unobservable extension evaluation criteria, such as credibility, quality and eventually customer patronage intentions (Keller and Aaker 1997). This seems particularly important when services are extended to markets in which the service provider has no proven expertise. Brands serve as cues for triggering image perceptions based on expressive values associated with the company name. Therefore, as Rao et al. (1997, p. 7) argue, empirical research into brand extensions should 'control for such psychological factors as brand imagery'.

As service extensions are taking place primarily in new and emerging markets (e.g., mobile telephony), innovativeness seems an important image priority. Because service brand extensions are primarily associated with new market entry strategies, innovation-related image attributes, such as order of entry (i.e., pioneers versus followers) seems relevant. However, the impact of perceived innovativeness with respect to service brand extensions has remained virtually unexplored so far.

In this article we attempt to gain a better understanding of aforementioned issues. Our approach is to take a number of findings from goods-related research and to extend them to a services setting, since extensions of previous research findings are crucial in the field of marketing. As Hubbard and Armstrong (1994, p. 233) note 'extensions play a valuable role in ensuring the integrity of a discipline's empirical results'. An extension focus helps to determine whether research results are valid, reliable and generalizable. This is particularly important in the case of experimental studies, which frequently suffers from the external validity controversy, as Winer (1999) has argued convincingly. Like brand extensions, the topic of this paper, research extensions contribute to the credibility and observable quality of scientific progress. Our paper is structured as follows. First, we offer a brief discussion of brand extensions and the central role of image in corporate brand extensions in services markets. Subsequently, we report on the 
results of an experimental study that has examined empirically the impact of new market entry strategies on customer evaluations of service extensions in the mobile telecommunications market. In conclusion, we will address the theoretical as well as the managerial implications of our findings.

\section{Brand Extensions: A Synthesis of the Literature}

\subsection{Extension similarity}

An important aspect of the brand extensions is the fit between the parent brand and the extension, or the extension similarity. As mentioned above, prior research in the field of brand extensions has primarily focused on the responses of consumers to brand extensions of manufactured goods (Aaker and Keller 1990; Park et al. 1991; Dacin and Smith 1994). As a result, a number of factors that influence consumer's evaluations of brand extensions have emerged (Aaker and Keller 1990; Boush and Loken 1991). These include the image of the parent brand, the information consumers have about the extension, and particularly the fit between the parent brand and the extension. With regard to the latter, consumers' evaluations of brand extensions depend in part on the similarity of the extension and the existing brand category and/or the relatedness of the market (Bridges 1992). The brand category consists of a brand name, a product or sets of products, key attributes (both functional and expressive) and attribute relationships, and is generally referred to as the brand schema. A brand schema represents all information consumers possess about the brand (Bridges 1992). Two brand schema dimensions have been identified in the literature (Bridges 1992; Keller and Aaker 1997; Park et al. 1991): (1) product related or concrete, functional associations and (2) non-product related or abstract, image based associations.

Both dimensions play a role in determining the similarity of the fit between the parent brand and the extension and consequently consumer evaluations of the extension (Park et al 1991; Bridges 1992; Aaker and Keller 1990; Broniarczyk and Alba 1994; Keller and Aaker 1992; Dacin and Smith 1994; Boush and Loken 1991; Keller and Aaker 1997). Product-level similarity depends on the relationship between the 
extension and the parent brand. When the extension shares the same attributes or the same usage-situations with the parent brand, the product-level similarity will be high. Image consistency depends on the extension's ability to reflect the brand concept, particularly when the extension is made to a new market. It will be high when the extension is consistent with the brand's meaning for consumers and when the extension and the parent brand share the same image-related associations. In this case, the most important basis of fit is what Aaker and Keller (1990) call transferability, i.e., the degree to which a firm operating in a product class is able to make products in another product class.

In general, studies of similarity or fit between the parent brand and the extension show a positive relation between the product similarity and consumers' evaluations of the extension. When the similarity is high, consumers base their evaluation of the extension on their attitude towards the parent brand (Keller and Aaker 1997). This means that extension evaluations are higher for well-established parent brands. When the similarity is low, consumers base their evaluation of the extension more on core attributes and benefits of the extension. However, in most cases, low similarity between parent brand and extension, whether in terms of related product class or related markets leads to lower levels of consumer acceptance, regardless of the strength of the parent brand (Keller and Aaker 1997; Boush and Loken 1991). In addition to the similarity between the parent brand and the extension, the distinction between corporate and product image plays a role. This is the topic of discussion in the next section.

\subsection{Corporate vs. product brands}

Most of the brand extension research to date has focused on product brand extensions, and not on the role of corporate-level associations in the evaluation of extensions. Keller and Aaker (1997, p. 6) conclude that: 
"In general, a corporate brand may be more likely to possess intangible attributes or organizational characteristics that span product classes than a product-brand whose associations are more likely to be product-specific."

Corporate brands influence the consumers' evaluation of the brand extension in a way which is different from product brands (Keller and Aaker 1997). Corporate brands represent the manufacturer of products or provider of services and, therefore, company perceptions may provide credibility about the source. In the advertising literature it has been shown that source credibility is an important determinant of consumer evaluations and response. With regards to the success of corporate brand extensions, Andrew (1998, p. 187) argues that the 'credibility of the brand in its new role is the single most important predictor'. In the case of corporate brand extensions, corporate credibility will affect the consumers' evaluations of the extension. Consumers will evaluate the extension higher when corporate credibility is high. Corporate credibility is especially important with respect to the credence attributes associated with services (Zeithaml and Bitner 1996). These force consumers to rely more on cues and information signals that are generally available to them, such as corporate image. Rao et al. (1997) state brands convey important information about a company's image. Andrew (1998) argues that extensions of corporate brands are in effect image transfers. Therefore, we turn to the concept of corporate image in relation to extension of service brand extensions.

In the services marketing literature, the (corporate) image concept has not featured prominently. Although some attention has been paid to the conceptualization of corporate image in services positioning (Grönroos 1993), the concept has remained vague. From the marketing of goods literature, it has become clear that corporate image represents the impressions and associations, the beliefs and attitudes that are held in consumer memory with regards to the company (Barich and Kotler 1991; Keller 1993). It has been referred to as 'personality' (Arons 1961) as well as a collection of symbolic associations with regards to 
the product (Finn 1985). The corporate image has also been described as 'the picture that an audience has of an organization through the accumulation of all received messages' (Ind 1997, p. 48).

The nature of these messages may differ between goods and services. As services are often defined as performances, rather than objects, they cannot be seen, felt, tasted or touched in the same matter in which goods can be sensed. Therefore, it is particularly important for services providers to have a strong corporate image to ensure the quality of their services and to stimulate word-of-mouth communication. The role of image becomes even more significant when competing services are perceived as virtually identical on performance, price, and availability (Andreassen and Lindestad 1998). Therefore, in the case of services, corporate image serves as an important factor influencing the perception of quality, consumers' evaluation of satisfaction with the service, and customer loyalty (Andreassen and Lindestad 1998). According to Grönroos (1993, p. 229) for service companies a corporate image is 'a filter which influences the perception of the operation of the company'. Consequentially, corporate image has been regarded as an information cue which may create a halo effect on customer judgments relating, for instance, to service provider credibility or the perceived quality of its services (Andreassen and Lindestad 1998). In new and emerging markets, a prevailing image priority has been the degree to which a company is perceived to be innovative (Keller and Aaker 1997; Shankar et al. 1998). Thus far, there has been little empirical evidence on the role of corporate image in services branding and its impact on customer evaluative judgments of service extensions in new and emerging markets. Therefore, we will develop a number of hypotheses with regards to this topic in the next section.

\section{The Role of Corporate Image in Service Brand Extensions: Development of Hypotheses}

In the new product development, innovativeness has been advanced as an essential image characteristic in terms of marketing effectiveness. With respect to manufactured goods, companies with an innovative image are typically associated with unique marketing programs, R\&D-oriented and being modern and up-to-date. There is ample evidence that innovative companies are perceived in more favorable terms than 
noninnovative firms in terms of credibility and expertise (Golder and Tellis 1993), perceived quality and purchase likelihood (Keller and Aaker 1997) and market share size (Robinson 1988). Recently, however, a number of studies have nuanced the impact of innovativeness empirically. It has been demonstrated that innovative late movers outperform pioneers in terms of brand sales and repeat purchases (Kalyanaram and Urban 1992; Bowman and Gatignon 1996; Shankar et al. 1998). While pioneers in innovation frequently define the category concept and must create buyer preferences, followers or innovative late entrants may be able to cater to blind spots in positioning, offer better prices or use more effective advertising and distribution strategies. Because of lower initiation costs, free-rider effects and learning from pioneer mistakes, a later entrant can achieve cost and differentiation advantages (Kerin et al. 1992). Indeed, Shankar et al. (1998) have shown for the market for pharmaceutical products that innovative late movers report higher repeat purchase rates than pioneers. In addition, by learning from the mistakes later entrants may develop superior technologies to produce and deliver better quality and develop higher levels of credibility (Kerin et al, 1992). We selected three extension evaluation criteria; (1) corporate credibility; (2) expected service quality; and (3) purchase intention. In general, the main reason for selecting these three extension evaluation criteria was the fact that these have frequently featured in previous extension research (see Keller and Aaker 1997 for an overview). Our purpose was to examine their determinants in the services setting. More specifically, it has been demonstrated in the brand extension, product innovation, services marketing, advertising as well as in the more recent electronic commerce literature that credibility functions is viewed as the achilles heel of success in aforementioned areas, due to the intangible nature and the credence properties of the phenomena. Moreover, in most models of customer evaluations of services the focus has been on a comparative judgment of expectations versus perceived performance resulting in the evaluative judgment of perceived service quality. Since perceived service quality is crucial in evaluations of any service, we propose to use it as a dependent variable in our design, reflecting the customer's attitude towards the extension. Finally, behavioral intentions, i.e., the intention of the customer to make use of the 
extension. As Davis and Venkatesh (1996) argue, an individual's intention to use is 'the single best predictor of actual usage'. Although empirical evidence so far pertains the marketing of goods, we feel that previous findings could be transferred to the area of service extensions also. Due to inherent characteristics of services such as intangibility and the difficulty consumers have in evaluating services before the moment of purchase, the impact of perceived risk may instigate consumers to favor innovative late service providers. Therefore, we hypothesize that:

$H_{1}$ : $\quad$ Consumers will evaluate service extensions by companies with an innovative late mover image more favorably than service extensions by companies with an innovative pioneer image in terms of the following evaluative criteria:
a.
corporate credibility
b. $\quad$ expected service quality
c. purchase intention

As was referred to above, many service providers are extending their brands to markets, which are beyond their traditional scope. With regard to the relation between the corporate brand extension and the parent brand, it has been argued that the similarity or fit between the parent brand and the extension shows a positive influence on consumers' evaluations of the extension (Park et al. 1991; Bridges 1992 and Keller and Aaker 1992). Aaker and Keller (1990) demonstrated that the perceived applicability of skills and expertise leads to this fit and hence to brand extension success. Alternatively, it has been argued that one of the major causes of brand extension failure is when the extension is perceived to be outside the perceived area of competence by potential customers (Andrew 1998). Therefore, market relatedness or extension similarity may be regarded as a success factor. Taking into account relatedness to the new market we formulate the following hypothesis:

$\mathrm{H}_{2}$ : $\quad$ Consumers will evaluate service extensions in a related market more favorably than services extensions in an unrelated market in terms of the following evaluative criteria: 

a. $\quad$ corporate credibility
b. $\quad$ expected service quality
c. purchase intention

Taking the interaction of both innovation entry image as well as market relatedness into account yields the following hypothesis:

$H_{3}$ : $\quad$ Consumers will evaluate service extensions by companies with an innovative late mover image in a related market more favorably than services extensions by companies with an innovative late mover image in an unrelated market in terms of the following evaluative evaluative criteria:
a. corporate credibility
b. $\quad$ expected service quality
c. purchase intention

Given the perceived risk associated with entering new unrelated markets as well as pioneering service providers and the relatively large number of brand extension failures cited in the literature (Andrew 1998), we expect that the relative difference between companies with a late mover image and companies with a pioneer image will be larger in unrelated markets. Therefore, we hypothesize that:

$H_{4}: \quad$ The relative difference between companies with a late mover image and companies with a pioneer image will be larger in unrelated markets than in related markets in terms of the following evaluative criteria:
$a$. corporate credibility
b. $\quad$ expected service quality
c. purchase intention

In the next section we report on an empirical test of our hypotheses. 


\section{An Experimental Study}

\subsection{Design and Manipulations}

A between-subjects, fixed-effects factorial design consisting of two factors was designed to test the aboveposited hypotheses. Corporate image was manipulated on three levels: (1) pioneer image, (2) innovative late mover, (3) control company with neutral image. The relation of the corporate brand extension with the current offerings of the service provider was manipulated on two levels: (1) extension into an unrelated market and (2) extension into a related market. Consequently, we have a 3 by 2 between subjects, fixedeffects factorial design. This factorial design allows the interaction of the factors to be studied (Keppel 1991). Corporate images were chosen because of the potentially different effects on the evaluation of the corporate brand extension. Hypothetical companies were used in our research design to avoid spill-over associations of existing corporate images. As a research setting, the market of mobile telecommunications was selected, the main reason being a relatively large number of service extensions have occurred recently as a result of which the range of mobile telephone networks has substantially increased in the Netherlands where the study was carried out.

\subsection{Questionnaire Design}

The manipulation of the image variants presented one of the major challenges in our study. Scenarios were developed to reflect the experimental design. Each scenario contained a description of the company and a description of the new service offering (see appendix I for a sample scenario). A control group for which no information about the corporate image was given, was also included in the questionnaire design. We opted for the use of fictitious company name on the basis of the rationale brought forward by Keller (1993) who argues that the use of real brand names may result in confounding problems and unintended effects beyond the focal effect to be tested. We let this theoretical rationale prevail over the advantages of face validity as a result of the use of real names. Furthermore, we included a measure of service category 
involvement to capture subjects' inherent service category attitudes and behavior and to acquire information on possible involvement bias.

The scenarios were developed after examining the market of mobile telecommunication, using desk research and conducting three in-depth interviews with product managers from the major players in this market. As mentioned above, a 3 by 2 between subjects, fixed-effects factorial design was used. Hence, six scenarios were then composed. In each scenario, after examining the company description and the service extension offering, respondents completed a set of closed questions with 7-point answering scales ranging from 1 ('Totally disagree') to 7 ('Totally agree') pertaining to the experimental manipulations, credibility (6 items; sample item 'Telphone is a trustworthy company'), expected service quality (8 items; sample item 'Telphone will deliver excellent service') and purchase intentions (3 items; sample item 'I will probably make use of this service'). The scales were largely based on the research by Keller and Aaker (1997). Finally, demographic variables, such as gender and age were collected.

\subsection{Pretest}

First of all, the scenarios were tested in the aforementioned in-depth interviews to ensure the that each scenario depicted a realistic situation. Subsequently, using simple random sampling 30 consumers (5 each for each scenario) were selected for a pretest. The pretest served three purposes: (1) to assess whether the desired state was induced by the manipulations of the independent variables; to test whether the fictitious names were considered meaningful and imagery-laden in line with the objectives of our study and (3) to assess the reliability and validity of the dependent measures. The subjects were interviewed immediately after exposure to the manipulation (Perdue and Summers 1986). The interviews revealed that the manipulations were successful in inducing the desired state of mind. Only minor adaptations were necessary for the scenarios. Moreover, preliminary analyses indicated that the dependent measures showed sufficient reliability in terms of coefficient alpha. 


\subsection{Procedure}

In total 299 respondents participated in this study. The respondents were randomly assigned to the six scenarios. Subjects were told that the purpose of the study was to learn more about the telecommunications market and the rapid developments that are taking place in it. Subjects were also told that they might normally make decisions about a new service on more information than would be provided by the scenario, but that it is important to learn how people evaluate a new service when they do not know much about the service and the company who is offering this service. In the sample, $67 \%$ of the respondents were male and $33 \%$ were female. Concerning the age of the respondents, most respondents were represented in the age group of 19 till 27 years. Of the respondents $2 \%$ were aged between 10 and 18 years, $35 \%$ between 19 and 27 years, $16 \%$ between 28 and 36 years, $13 \%$ between 37 and 45 years, $27 \%$ between 46 and 54 years, and $8 \%$ were 55 years or older. Finally, $16 \%$ of the respondents already had a mobile telephone.

\section{Results}

\subsection{Manipulation Checks}

Manipulation checks were executed in order to assess whether the intended manipulations were understood by the respondents. Furthermore, Sternthal et al. (1987) argue that ultimately the effectiveness of the manipulations is reflected in pattern of the resulting data. Respondents completed a set of closed questions with 7-point answering scales ranging from 1 ('Totally disagree') to 7 ('Totally agree') pertaining to the experimental manipulations. The results of the manipulation checks show that there are differences in terms of image. Our analysis demonstrates that the company with an pioneer image was seen significantly more as a trendsetter $(\mathrm{F}(1,297)=44.37 ; \mathrm{p}<0.0001)$ and this company was also significantly seen more as a first-mover $(\mathrm{F}(1,297)=30.85 ; \mathrm{p}<0.0001)$. The company with a late mover image was perceived significantly more as a follower $(F(1,297)=72.00 ; \mathrm{p}<0.0001)$. The results also suggested that there were 
differences between the company, which extended the new service in the same market, and the company, which extended the new service in a different market. The companies which offer the new service in the market they already operate in show more fit between the extension and the current offerings $(\mathrm{F}(1,297)=57.80 ; \mathrm{p}<0.0001)$, and between the extension and the company itself $(\mathrm{F}(1,297)=57.85$; $\mathrm{p}<0.0001)$. Consumers also perceived that it will be a logical step to offer the new service for the company which already operates in the market $(F(1,297)=61.29 ; \mathrm{p}<0.0001)$.

\subsection{Reliability and Validity of the Dependent Measures}

We carried out exploratory factor analysis to assess whether the three variables would load on separate factors. Our analysis revealed that all items loaded highly (>0.5) and exclusively on their hypothesized factors, using principal axis factoring and oblique rotation. This indicates that the three measures are tapping different concepts. The three-factor model explained a substantial part of total variance (68\%).

\section{[INSERT TABLE 1 ABOUT HERE]}

Furthermore, reliability analysis revealed that coefficient alpha for the three dependent measures exceeded 0.8 (See Table 1).

\subsection{Hypotheses Testing}

We started with testing whether the innovative late mover image and the pioneer image differ significantly from the control company with a neutral image. Using multiple single degree of freedom tests, we found that both the innovative late mover image and the pioneer image were significantly different from the control company with a neutral image $(\alpha=0.05)$.

For analysis of the research hypothesis $\left(\mathrm{H}_{1}-\mathrm{H}_{4}\right)$ we used planned contrasts (Keppel 1991; Schoorman et al. 1991; Umesh et al 1996). However, before discussing the results of these analyses we will first provide the omnibus MANOVA tests and the omnibus ANOVA tests for the design (Bray and Maxwell 1993).

[INSERT TABLE 2 ABOUT HERE] 
The results of omnibus MANOVA tests are summarized in Table 2. We found an interaction effect for the interaction between corporate image $(\mathrm{CI})$ and extension similarity $(\mathrm{ES}) \quad(\mathrm{V}=0.13 ; \mathrm{F}(6,582)=6.76$; $\mathrm{p}<0.001)$. Furthermore, we found that extension similarity $(\mathrm{ES})$ exhibit a significant main effect $(\mathrm{V}=0.05$; $\mathrm{F}(3,291)=5.05 ; \mathrm{p}=0.002)$. For corporate image $(\mathrm{CI})$ we did not find a significant main effect $(\mathrm{V}=0.02$; $F(6,582)=1.12 ; p=0.349)$.

\section{[INSERT TABLE 3 ABOUT HERE]}

These effects are supported by omnibus ANOVA tests for the individual dependent measures (Bray and Maxwell 1993; Neter et al. 1990; Umesh et al. 1996) in Table 3.

The research hypotheses were analyzed using planned contrasts (Keppel 1991; Neter et al. 1990; Umesh et al. 1996). Regarding $\mathrm{H}_{1}$ we find that service brand extensions by companies with an innovative late mover advantage are evaluated more favorable than companies with an innovative pioneer image in terms of corporate credibility $(\mathrm{t}(293)=1.90 ; \mathrm{p}=0.029)$ and expected service quality $(\mathrm{t}(293)=1.96$; $\mathrm{p}=0.026$ ). For $\mathrm{H} \underline{\mathrm{L}}$ our results indicate that service brand extensions are evaluated more favorably in a related market than in an unrelated market in terms of corporate credibility $(\mathrm{t}(293)=3.20 ; \mathrm{p}=0.001)$, expected service quality $(\mathrm{t}(293)=2.97 ; \mathrm{p}=0.002)$ and purchase intention $(\mathrm{t}(293)=2.10 ; \mathrm{p}=0.019)$. With respect to $\mathrm{H}_{3}$ the results of our analyses suggest that service brand extensions by companies with an innovative late mover image in a related market are more favorably evaluated than service brand extensions by companies with an innovative late mover image in an unrelated market in terms of corporate credibility $(\mathrm{t}(293)=2.67 ; \mathrm{p}=0.004)$ and expected service quality $(\mathrm{t}(293)=2.56 ; \mathrm{p}=0.006)$. Finally, with regard to $\mathrm{H}_{4}$ we find that the relative difference between companies with an innovative late mover image and companies with a pioneer image will be larger in unrelated markets in terms of corporate credibility $(\mathrm{t}(293)=1.87$; $\mathrm{p}=0.03)$ and expected service quality $(\mathrm{t}(293)=1.66 ; \mathrm{p}=0.048)$. The cell means are graphically represented in Figure 1 (See Umesh et al. 1996).

[INSERT FIGURE 1 ABOUT HERE] 


\section{Conclusions and implications}

In this study we examined the role of corporate image and extension similarity in the case of service brand extensions in the telecommunications market. The purpose of the paper was to examine whether some important findings reported in the marketing of goods literature are transferable to a services setting, a question which seems increasingly relevant considering recent developments in a number of service industries. In terms of two service provider evaluation criteria (i.e., perceived corporate credibility and expected service quality) it was found that consumers evaluate service extensions by providers with an innovative late mover image more favorably than service extensions by companies with a pioneer image. This is constant with findings from the marketing of goods literature (e.g., Golder and Tellis 1993). It appears that consumers exhibit higher trust in both the corporate brand and the level of expected service quality of service providers that follow the moves of pioneering competitors. This may be attributed to the fact that due to the relative high degree of perceived risk associated with technology-based services, potential customers have a preference for service providers that learn from their competitors' mistakes. In addition, research into preference formation (Carpenter and Nakamoto 1994) suggests that by successfully dealing with problems, solutions offered by late innovators may set a new standard, thereby gaining an advantage over the pioneer. In addition, we see that the control company (no relevant corporate image was rendered) shows consistently lower ratings on the three dependent variables. This signifies that image is an important evaluation determinant. Image (whether pioneer or innovative late move) apparently is an information cue that consumers use to judge matters such as credibility, perceived quality and purchase intentions. We also found that for two of the three service extension evaluation criteria (i.e., perceived corporate credibility and expected service quality) extension similarity is preferred over service brand extensions to unrelated markets. This finding is also consistent with previous research in the marketing of goods literature (e.g., Bridges 1992) which is indicative of the significant impact of the fit between the parent brand and the extension. Aforementioned findings are further nuanced by a significant interaction 
effect between corporate image and extension similarity. In addition we find that the relative distance between service providers with an innovative late mover image and pioneers is larger in related markets.

It should be noted, however, that the pattern described above does not appear to apply to consumer purchase intentions. Apparently, this type of customer evaluative judgment differs from the credibility and quality criteria. It may very well be that other (marketing mix) criteria, such as price or the range of the distribution network, rather than corporate image and extension similarity are determinants of customer purchase intentions. An additional explanation may be attributed to limitations of the research design. Part of the strength of any research project lies in recognizing these and taking them as points of direction for further research.

First of all, partial support for our hypotheses in terms of non-significance for the purchase intention variable may be due to the fact that respondents find it difficult to express purchase intentions regarding hypothetical companies, even though the results of the manipulation check reveal successful manipulation. Extending our findings to experimental designs that make use of real-life names and service extensions, possibly by using audio-visual scenarios, may yield additional insight in the matter of external validity. Furthermore, additional research is needed to take actual consumer, rather than intentions, into account. Also, future research should to explore the issues introduced in our study over a broader set of services, as the focus was limited to the mobile telecommunication market only. Moreover, it may be that the impact of corporate image as well as extension similarity behaves differently depending on the type of service and consumer perceptions of it. For instance, it is conceivable that the role of corporate image may play a stronger role in the case of high involvement services rather than low involvement services. Motivational as well as ability issues (Petty and Cacciopo 1986), for instance, play a role in varying involvement levels. Also, personal characteristics such as mobile telephone experience and familiarity and personality characteristics ('degree of innovativeness') might yield a further insight into the relationships between the variables that were introduced in our research design. Finally, our study was limited to the role of corporate 
image and extension similarity. In future research the impact of other marketing mix variables, such as price, should be taken into account, in order to investigate drivers of consumer purchase intentions and actual behavior.

A number of managerial implications emerge from our research. First of all, our results are indicative of fact that 'it may pay to wait'. Apparently, many consumers prefer a brand that 'tries harder' or 'studies the successful and tries to do better'. This is what Alpert and Kamins (1994) label the classic Avis approach. This implies that followers should communicate that they have carefully studied the service extension marketed by competitors ('brand benchmarking'), offering the best of pioneer service attributes plus valueadded benefits. Another consequence is that in addition to spending resources on marketing instruments with the aim of establishing the service extension on the market, followers may spend more on redefining the service extension, beating pioneering service brands at their own game. This research points out that by affecting customer perceptions of innovative late movers a considerable boost to a service extension can be achieved. A second implication for corporate branding strategies by service providers is that emphasizing similarity between the parent brand and the service extension may increase the likelihood of more favorable consumer evaluations. Apparently, service extensions that are beyond the current service scope of the firm result in lower levels of consumer confidence in the extension. Currently, many service extensions are based on joint venture projects of service providers that are active in both related and unrelated markets. For instance, the Dutch Railways and British Telecom have partnered in the mobile telecommunications market. In terms of extension similarity it seems advisable to emphasize the British Telecom experience telecommunications. Finally, for companies that look to extend their services to new markets that are unrelated to the market in which they are traditionally have been active, brand communications should be emphasizing what the brand stands for and what it means to the consumer (i.e., expressive values of the brand) rather than focusing on technical or functional service values. 
-18- 


\section{References}

Aaker, D.A. and K.L. Keller, 1990. Consumer Evaluations of Brand Extensions. Journal of Marketing 54 (January), 27-41.

Alpert, F.H. and M.H. Kamins, 1994. Pioneer Brand Advantage and Consumer Behavior: A Conceptual Framework and Propostional Inventory. Journal of the Academy of Marketing Science 22, 244-253.

Andreassen, T.W. and B. Lindestad, 1998. Customer Loyalty and Complex Services. International Journal of Service Industry Management 9 (1), 7-23.

Andrew, D., 1998. Brand Revitalisation and Extension. In: S. Hart and J. Murphy (Eds.), Brands: The New Wealth Creators. MacMillan, London, 184-195.

Arons, L., 1961. Does television viewing influence store image and shopping frequency? Journal of Retailing 37, 1-13.

Barich, H. and P. Kotler, 1991. A Framework for Marketing Image Management. Sloan Management Review Winter, 94-104.

Boush, D.M. and B. Loken, 1991. A Process-Tracing Study of Brand Extension Evaluation. Journal of Marketing Research 28 (February), 16-28.

Bowman D. and H. Gatignon, 1996. Order of Entry as a Moderator of the Effect of the Marketing Mix on Market Share. Marketing Science 15, 222-242.

Bray, J.H. and S.E. Maxwell 1993. Multivariate Analysis of Variance. In: M.S. Lewis-Beck, Experimental Design and Methods. Sage Publication/Toppan Publishing, London, 337-408.

Bridges, S., 1992. A Schema Unification Model of Brand Extensions. Working Paper Report No. 92-123 August, Wake Forest University, Cambridge, Massachusetts.

Broniarczyk, S.M. and J.W. Alba, 1994. The Importance of the Brand in Brand Extension. Journal of Marketing Research 31 (May), 214-228. 
Carpenter, G.S. and K. Nakamoto, 1994. Reflections on Consumer Preference Formation and Pioneering Advantage. Journal of Marketing Research 39 (November), 570-573.

Dacin, P.A. and D.C. Smith, 1994. The Effect of Brand Portfolio Characteristics on Consumer Evaluations of Brand Extensions. Journal of Marketing Research 31 (May), 229-242.

Davis, F. D., and Venkatesh, V. 1996. A critical assessment of potential measurement biases in the technology acceptance model: Three experiments. International Journal of Human - Computer Studies, $45,19-45$.

Finn, A., 1985, A theory of the consumer evaluation process for new product concepts, in J.N. Sheth (ed.) Research in Consumer Behavior 1, 35-65.

Golder, P.N. and G.J. Tellis, 1993. Pioneer Advantage: Marketing Logic or Marketing Legend? Journal of Marketing Research 30 (May), 158-170.

Grönroos, C., 1993. Services Marketing and Management. Lexington, Lexington Books.

Hart, S. and J. Murphy, 1998. Brands: The New Wealth Creators. MacMillan, London.

Ind, D. (1997), The Corporate Brand. MacMillan, London.

Hubbard, R. and J. Scott Armstrong, 1994. Replications and extensions in marketing: Rarely published but quite contrary. International Journal of Research in Marketing 11, 233-248.

John, D.R. and B. Loken, 1992. Diluting Beliefs About Family Brands: When Brand Extensions Have a Negative Impact. Working Paper Report No. 92-122 August, University of Minnesota, Cambridge, Massachusetts.

Kalyanaram, G. and G.L. Urban, 1992. Dynamic Effects of the Order of Entry on Market Share, Trial Penetration and Repeat Purchases for Frequently Purchased Consumer Goods. Marketing Science 11, $235-250$.

Keller, K.L., 1993. Conceptualizing, Measuring and Managing Brand Equity, Journal of Marketing 57, 122. 
Keller, K.L. and D.A. Aaker, 1992. The Effects of Sequential Introduction of Brand Extensions. Journal of Marketing Research 29 (February), 35-50.

Keller, K.L. and D.A. Aaker, 1997. Managing the Corporate Brand: The Effect of Corporate Marketing Activity on Consumer Evaluations of Brand Extensions. Working Paper Report No. 97-106 May, Marketing Science Institute.

Keppel, G.,1991. Design and Analysis: A Researcher's Handbook. Prentice-Hall, Englewood Cliffs, NJ.

Kerin, R.A., P.R. Varadarajan and R.A. Peterson, 1992. First-Mover Advantage: A Synthesis, Conceptual Framework, and Research Propositions. Journal of Marketing 56 (October), 33-52.

Kirmani, A., S. Sood and S. Bridges, 1997. The Ownership Effect in Consumer Responses to Brand Line Stretches. Working Paper Report No. 97-128 December, Marketing Science Institute.

Park, C.W., S. Milberg and R. Lawson, 1991. Evaluation of Brand Extensions: The Role of Product Feature Similarity and Brand Concept Consistency. Journal of Consumer Research 18 (September), 185-193.

Petty, R.E. and J. T. Cacioppo, 1986. Communication and Persuasion. Springer Verlag, New York.

Perdue, B.C. and J.O. Summers, 1986. Checking the Success of Manipulations in Marketing Experiments. Journal of Marketing Research 23 (November), 317-326.

Rao, A., L. Qu and R.W. Ruekert, 1997. Brand Alliances as Information About Unobservable Product Quality. Working Paper Report No. 97-100 March, Marketing Science Institute.

Robinson, W.T., 1988. Sources of Market Pioneer Advantages: The Case of Industrial Goods Industries. Journal of Marketing Research 25 (February), 87-94.

Roedder John, D., B. Loken and C. Joiner, 1998. The Negative Impact of Extensions: Can Flagship Products be Diluted? Journal of Marketing 62, 19-32. 
Schoorman, F.D., P. Bobko and J. Rentsch 1991. The Role of Theory in Testing Hypothesized Interactions: An Example From the Research on Escalation of Commitment. Journal of Applied Social Psychology 21 (August), 1338-1355.

Shankar, V., G. Carpenter and L. Krishnamurthi, 1998. Late Mover Advantage: How Innovative Late Entrants outsell Pioneers. Journal of Marketing Research 35, 54-70.

Sternthal, B., Tybout, A.M. and B.J. Calder, 1987. Confirmatory Versus Comparative Approaches to Judging Theory Tests. Journal of Consumer Research 18 (June), 114-125.

Tabachnik, B.G. and L.S. Fidell, 1996. Using Multivariate Statistics. Harper Collins College Publishers, New York.

Umesh, U.N., Peterson, R.A., McCann-Nelson, M. and R. Vaidyanathan, 1996. Type IV Error in Marketing Research: The Investigation of ANOVA Interactions. Journal of the Academy of Marketing Science 24 (1), 17-26.

Winer, R.S., 1999. Experimentation in the 21st century: the importance of external validity. Journal of the Academy of Marketing Science 27 (3), 349-358.

Zeithaml, V.A. and M.J. Bitner, 1996. Services Marketing. McGraw-Hill, New York. 
Table 1: Descriptive Measures for the Dependent Variables

\begin{tabular}{llcccc}
\hline & M & SD & \multicolumn{2}{c}{ Intercorrelations $^{\mathbf{a}}$} & 2. \\
\hline 1. Corporate Credibility & 4.66 & 0.99 & $\mathbf{0 . 8 1}$ & & \\
2. Expected Service Quality & 4.34 & 1.09 & $0.52^{* *}$ & $\mathbf{0 . 8 9}$ & \\
3. Purchase Intention & 4.17 & 1.11 & $0.31^{* *}$ & $0.42^{* *}$ & $\mathbf{0 . 8 2}$ \\
\hline
\end{tabular}

a Coefficient á on diagonal.

** Significant at á=0.01. 
Table 2: Results of Omnibus MANOVA Tests

\begin{tabular}{lcrcc}
\hline Effect & Pillai-Bartlett trace (V) & F & Df & P-value \\
\hline \multicolumn{5}{c}{ Main Effects } \\
\hline Corporate Image (CI) & 0.02 & 1.12 & 6,582 & 0.349 \\
Extension Similarity (ES) & 0.05 & 5.05 & 3,291 & 0.002 \\
& \multicolumn{5}{c}{ Two-Way Interaction } \\
\hline CI $*$ ES & 0.13 & 6.76 & 6,582 & $<0.001$ \\
& & & \\
\hline
\end{tabular}


Table 3: Results of Omnibus ANOVA Tests

Corporate Credibility

\begin{tabular}{|c|c|c|c|}
\hline Effect & $\mathbf{F}$ & Df & P-value \\
\hline \multicolumn{4}{|c|}{ Main Effects } \\
\hline Corporate Image (CI) & 2.73 & 2,293 & 0.067 \\
\hline Extension Similarity (ES) & 13.22 & 1,293 & $<0.001$ \\
\hline \multicolumn{4}{|c|}{ Two-Way Interaction } \\
\hline $\mathrm{CI} * \mathrm{ES}$ & 21.13 & 2,293 & $<0.001$ \\
\hline
\end{tabular}

Expected Service Quality

\begin{tabular}{lccc} 
Effect & F & Df & P-value \\
\hline & \multicolumn{3}{c}{ Main Effects } \\
\hline Corporate Image (CI) & 1.65 & 2,293 & 0.194 \\
Extension Similarity (ES) & 8.24 & 1,293 & 0.004 \\
& \multicolumn{2}{c}{ Two-Way Interaction } \\
\hline CI $*$ ES & 8.41 & 2,293 & $<0.001$ \\
\hline
\end{tabular}

Purchase Intention

\begin{tabular}{lccc}
\hline Effect & F & Df & P-value \\
\hline & \multicolumn{2}{c}{ Main Effects } \\
\hline Corporate Image (CI) & 0.61 & 2,293 & 0.544 \\
Extension Similarity (ES) & 5.03 & 1,293 & 0.026 \\
& \multicolumn{2}{c}{ Two-Way Interaction } & \\
\hline $\mathrm{CI} * \mathrm{ES}$ & 4.32 & 2,293 & 0.014 \\
\hline
\end{tabular}




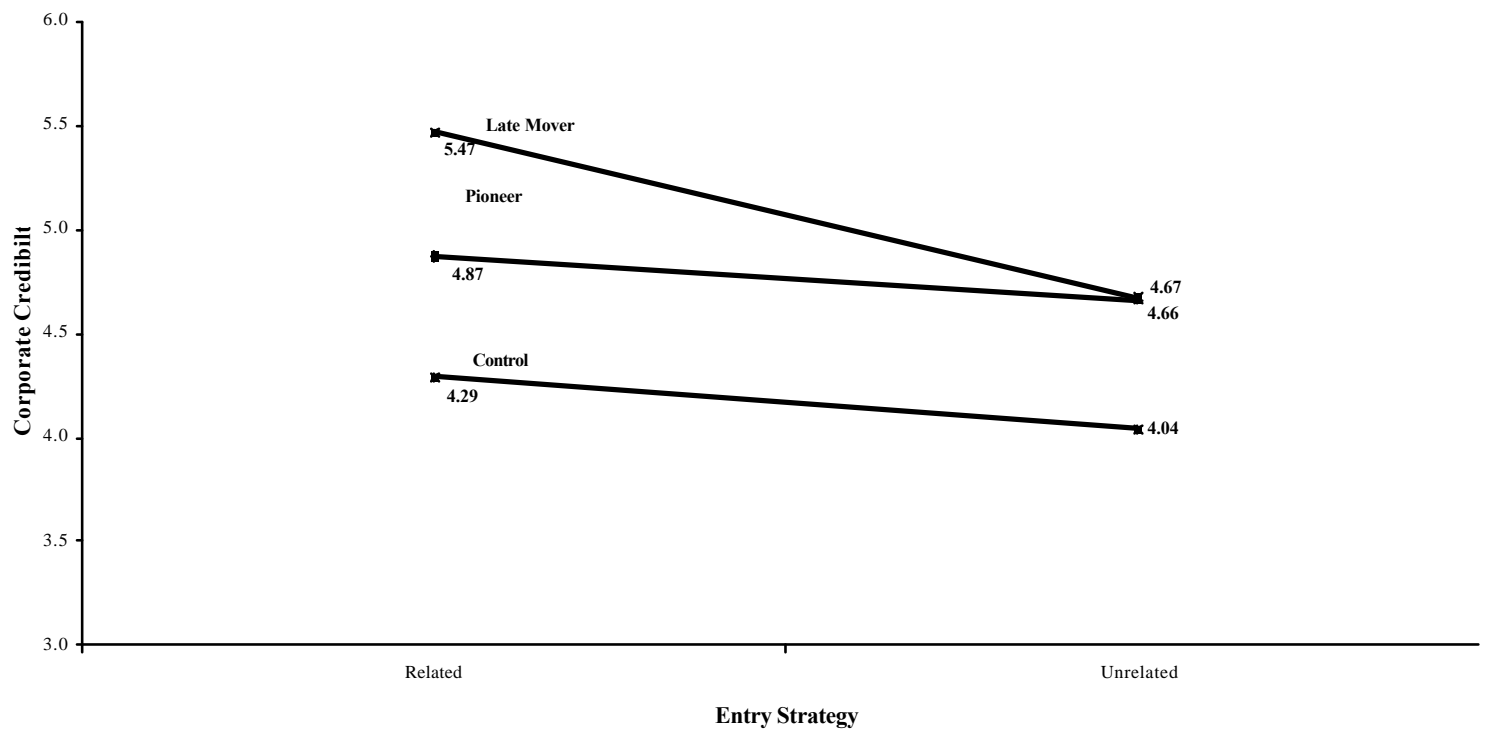




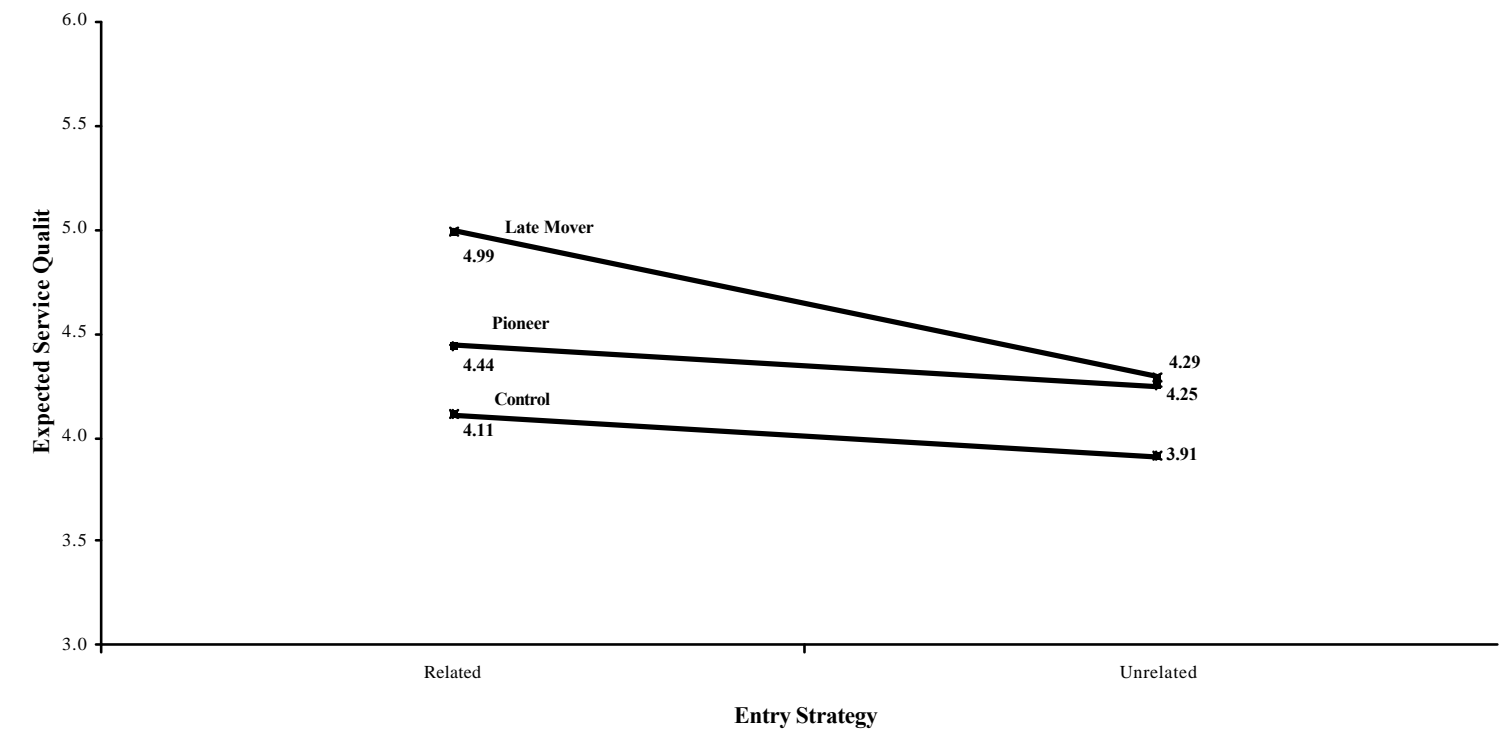




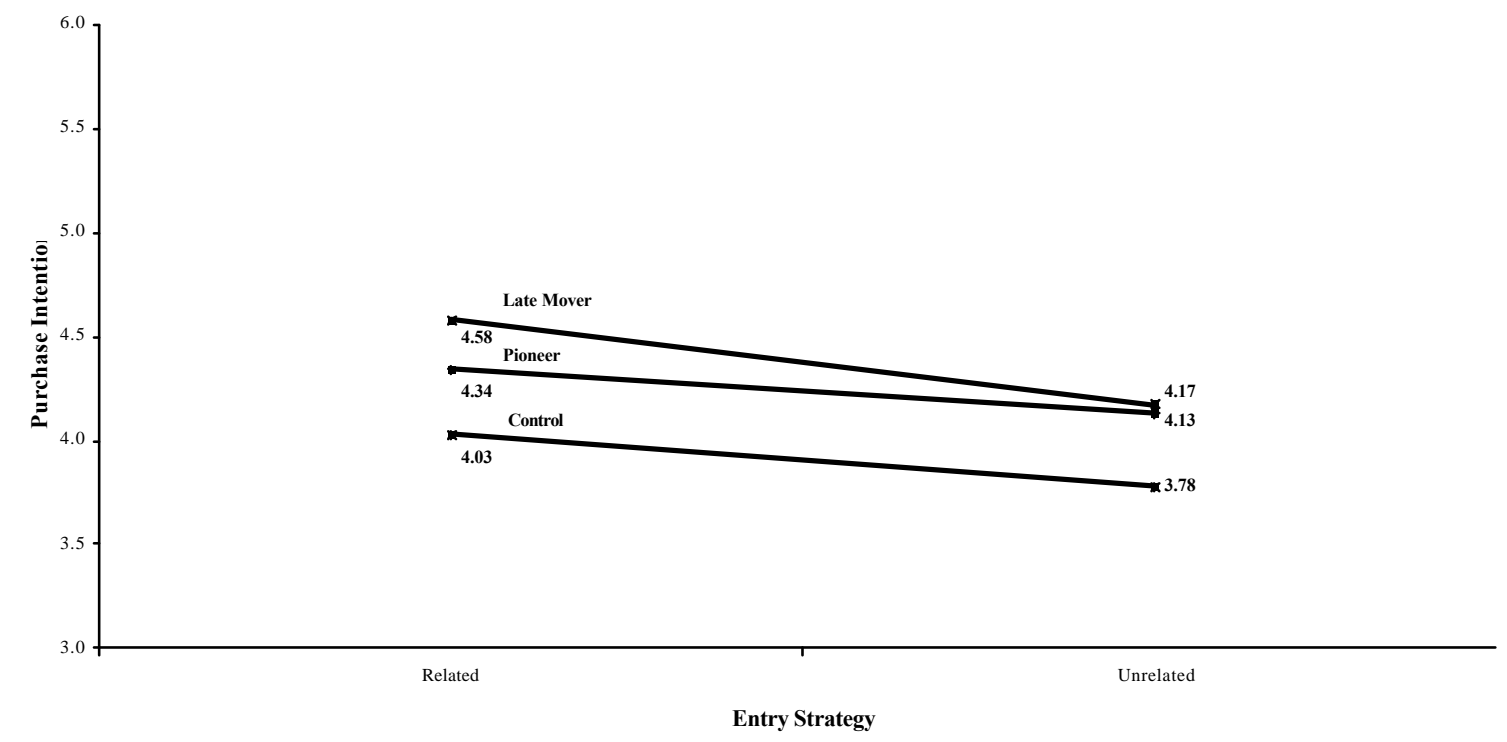




\section{Appendix I: Sample Scenarios}

\section{(pioneer/related market)}

For a number of years, the Telphone company has been active as a major player in the market for internal communications systems for large corporations. The company is specialized in all aspects of telecommunication within companies. Telphone has a reputation for introducing the latest technology in the area of telecommunications. It is a leading company as far as innovations in telecommunication technology as well as superior customer service are concerned. The company invests a considerable amount of resources in research and development. In this way, Telphone wants to be a trendsetter and is very successful at it.

As a consequence of requests from their major customers and the expertise acquired in the field of telecommunications, Telphone has decided to extend its services to the market of consumer mobile telephony. In doing so, it is using its experience in the telecommunication area in order to become a trendsetter in this new market as well. In addition to the basic service of mobile telecommunication Telphone has been the first to introduce a whole range of extras, such as voice recognition, billing per second, 24 hour support and a large variety of caller subscription programs. Moreover, Telphone is the first company to introduce a 4 hour telephone replacement service.

\section{(innovative late mover/unrelated market)}

For a number of years, the NetCai company has been active as a major player in the market for cable services. The company is specialized the digitial transmission of television and radio programs. NetCai has a reputation for implementing the latest technology in its market immediately after competitors have introducted it. In doing so it is able to offer state-of-the art solutions without the bugs of first time introductions. At the same time, the company is well-renowned for its superior customer service. The company invests a considerable amount of resources in scanning the market place for new developments. In this way, NetCai wants to be an innovator but not an inventor, a trend watcher but not a trendsetter.

NetCai has decided to extend its services to the market of consumer mobile telephony via CaiPhone, because it has become clear that there are great opportunities in this market. Using its experience as a trend watcher the company's aim is to become a leading company in the telecommunication area as well. In addition to the basic service of mobile telecommunication, NetCai has been rapidly adopting the service innovations offered by other mobile telcom providers, such as voice recognition, billing per second, 24 hour support and a large variety of caller subscription programs.

\section{(neutral/related market)}

For a number of years, the Telphone company has been active a provider of internal communications systems for large corporations. It has several offices all over the country.

As a consequence of requests from their major customers and the expertise acquired in the field of telecommunications, Telphone has decided to extend its services to the market of consumer mobile telephony. In doing so, it is using its experience in the telecommunication area in order to be successful in this rapidly developing market. A number of services that have been developed for internal communications systems can easily be transfered to the market for mobile telecommunications. 